\title{
The Relative Significance of Biological and Physical Disturbance: an Example from Intertidal and Subtidal Sandy Bottom Communities
}

\author{
Thomas Brey \\ Alfred Wegener Institute for Polar and Marine Research, Columbusstrasse, \\ D-2850 Bremerhaven, Germany
}

Received 26 fuly 1990 and in revised form 19 February 1991

\begin{abstract}
Keywords: disturbance; hydrodynamics; bioturbation; Arenicola marina; interactions

The effects of biological disturbance caused by the lugworm Arenicola marina (L.) on the abundance of the macrobenthic fauna were investigated at three subtidal stations $(0.5 \mathrm{~m}, 12 \mathrm{~m}$ and $19 \mathrm{~m}$ water depth) in Kiel Bay (western Baltic) and on an intertidal flat in the German Wadden Sea. Different effects of biological disturbance were observed (1) between funnel and cast of the lugworm burrow, (2) among stations, (3) between scasons, and (4) among taxa and groups of different living mode of the macrofauna. The strength of the impact of $A$. marina on the abundance of a certain macrobenthic species depends on three factors: (1) spccics bchaviour and living mode, (2) A. marina activity, and (3) hydrodynamic conditions. In general, the most distinct effects were observed at the intertidal station during summer, followed by the two deeper subtidal stations. At the very shallow station, only weak effects were detceted.
\end{abstract}

\section{Introduction}

The factors which control structure and dynamics of communities are central themes of theoretical and applied ecology. Besides competition (e.g. MacArthur \& Wilson, 1967) and predation (e.g. Paine, 1966), disturbance plays a key role in various theoretical approaches (e.g. Gray, 1984; Huston, 1979; Menge \& Sutherland, 1987). The significance of large-scale physical disturbance has already become an integral element of models which try to explain community development and succession (e.g. Connell \& Slayter, 1977; Gray, 1977; Sanders, 1968). With respect to marine soft-bottom communities, small-scale disturbance, either physically or biologically induced, was first taken into account by Grassle and Sanders (1973) and has become a focus of interest over recent years (Bell \& Devlin, 1983; van Blaricom, 1982; Brenchley, 1981; DeWitt, 1987; Eckman, 1979; Hall et al., 1990; Probert, 1984; Savidge \& Taghon, 1988; Smith et al., 1986; Smith et al., 1986; Thrush et al., 1991; Wilson, 1981; Woodin, 1978, 1981, 1985; Zajac \& Whitlatch, 1982). 
TABLE 1. Abiotic parameters and sampling regime at the four stations. Salinity and water temperature data from Asmus (1984, WH), Babenerd (1980, GF and BE), and Stienen $(1986, \mathrm{KF})$

\begin{tabular}{|c|c|c|c|c|}
\hline Station & $\mathrm{KF}$ & GF & $\mathrm{BE}$ & WH \\
\hline \multicolumn{5}{|l|}{ Water } \\
\hline Water depth (m) & $0-1$ & 12 & 19 & $0-1^{h t}$ \\
\hline Salinity ${ }^{a}(\%)$ & $10-20$ & $16-20$ & $9-22$ & $26-31$ \\
\hline Water temperature ${ }^{a}\left({ }^{\circ} \mathrm{C}\right)$ & $2-20$ & $2-14$ & $2-13$ & $1-20$ \\
\hline \multicolumn{5}{|l|}{ Sediment } \\
\hline$>0.25 \mathrm{~mm}$ & $20 \cdot 9$ & $47 \cdot 3$ & $30 \cdot 0$ & $14 \cdot 1$ \\
\hline $125-0.25 \mathrm{~mm}$ & $63 \cdot 0$ & $49 \cdot 4$ & $53 \cdot 5$ & $73 \cdot 0$ \\
\hline $63-125 \mu \mathrm{m}$ & $14 \cdot 3$ & $3 \cdot 1$ & $12 \cdot 8$ & $6 \cdot 8$ \\
\hline$<63 \mu \mathrm{m}$ & $1 \cdot 8$ & $0 \cdot 3$ & $3 \cdot 7$ & $3 \cdot 2$ \\
\hline \multicolumn{5}{|l|}{ Sampling } \\
\hline Sampling period & $9 / 87$ and $12 / 87$ & $9 / 86-6 / 88$ & $2 / 88-5 / 88$ & $7 / 87-6 / 88$ \\
\hline No. of sampling dates & 2 & 13 & 3 & 4 \\
\hline No. of samples per day & $5 \times 3$ & $3 \times 3 / 4 \times 3^{d}$ & $4 \times 3$ & $5 \times 3$ \\
\hline Total no. of samples & 30 & 126 & 36 & 60 \\
\hline
\end{tabular}

${ }^{a}$ Annual variation.

${ }^{b}$ Intertidal, 6-h immersion per 12-h tidal cycle.

Three samples per $A$. marina burrow: funnel, cast and control.

${ }^{d}$ Increase from $3 \times 3$ to $4 \times 3$ samples in September 1987 .

In shallow water soft-bottom communities, hydrodynamics are the main source of large-scale physical disturbance, whereas bioturbation is one important source of smallscale biological disturbance. Large deposit-feeding infaunal species which deposit their faeces at the sediment surface, e.g. arenicolid polychaetes (summary in Cadée, 1976), holothurians such as Leptosynapta tenuis (Myers, 1977a,b) and Molpadia oolithica (Rhoads \& Young, 1971) or enteropneusts such as Balanoglossus auratiacus (Duncan, 1977), are known as major bioturbators.

The present paper evaluates the significance of biological disturbance caused by the lugworm Arenicola marina under different hydrodynamic regimes, i.e. at several sites and in different seasons of the year. The aim was to analyse the interactions between smallscale biological and large-scale physical disturbance and to describe possible synergistic effects on the macrobenthic community.

\section{Methods}

\section{Sampling sites}

Samples were taken at four different stations, the subtidal stations KF, GF and BE in Kiel Bay (western Baltic) and the intertidal station WH in the German Wadden Sea. The sediment of all stations consisted of medium and fine sand with a low content of clay and silt (Table 1). Station KF is situated in a particular area of the Kiel harbour constructions, which is silting up continuously due to the local wind and current conditions. The sand bank has a gentle slope (1:15) down to about $1 \mathrm{~m}$ water depth, and the upper millimetres of sediment are almost continuously resuspended as a result of ship- and wind-induced waves. Sometimes, during strong southerly winds, the bank becomes completely exposed to the air. Station GF is situated at a subtidal flat north of Kiel lighthouse in $12 \mathrm{~m}$ water 
depth, which is exposed to wave and current activities from all directions. Strong gales lead to wave-induced sand ripple formation, but these events are very rare during summer. The calculations of Boehlich and Backhaus (1987), Schweimer (1976) and Struve-Blanck (1982) indicate that during the summer bottom water current speeds above $10 \mathrm{~cm} \mathrm{~s}^{-1}$ rarely occur at station GF.

Station BE is situated on the slope of the west coast of Kiel Bay at $19 \mathrm{~m}$ water depth and is well protected against disturbance due to waves, because most gales in this area are of south-western origin.

Station WH is located in a tidal flat of the German Wadden Sea close to the lighthouse Westerhever; it is immersed for about $6 \mathrm{~h}$ per tidal cycle, i.e two times a day.

\section{Sampling and sorting}

All samples were taken by hand-operated ( $\mathrm{KF}$ and $\mathrm{WH}$ ) or diver-operated (GF and BE) corers $\left(27 \mathrm{~cm}^{2}, 10 \mathrm{~cm}\right.$ sampling depth). Three parallel samples were taken at each $A$. marina burrow which had been selected for sampling: one at the funnel, one at the cast, and one control sample from assumed unaffected area close to the burrow. Between 1986 and 1988, 252 (i.e. $84 \times 3$ ) samples were taken (Table 1).

The samples were fixed in a seawater solution of $0.4 \%$ formaldehyde and $3^{\circ}{ }_{0}$ Kohrsolin (see Brey, 1989), stained with Bengal rose, and sieved with $0.50 \mathrm{~mm}$ and $0.25 \mathrm{~mm} \mathrm{mcsh}$ size in the laboratory. Animals in the $0.50-\mathrm{mm}$ fraction were identified to species level, whereas the $0 \cdot 25$-mm fraction was separated into molluscs (i.e. mainly O-group animals of the most abundant bivalve species), polychaetes (including oligochaetes) and crustaceans.

Abundance of adult $A$. marina was estimated from the number of casts at the sediment surface. At stations GF and BE a submersible video-camera system (Cyclops ${ }^{T M}$ ) was used in addition to observations made by divers.

\section{Sample analysis}

The samples collected were analysed with respect to two main questions: Do the burrows of $A$. marina, i.e. funnels and casts, affect macrofaunal abundance significantly? Are the effects of funnels and casts different among sampling stations, seasons or macrobenthic groups?

The fauna was grouped into bivalves, gastropods, sessile polychaetes (including hemisessile species such as spionids), motile polychaetes (including oligochaetes) and crustaceans for multivariate tests; univariate tests were applied to different levels from all species combined to single species.

Macrofaunal abundance in funnel, cast and control samples was compared either by ANOVA of the Box-Cox-transformed data or by the non-parametric Kruskal-Wallis test, if the requirements for ANOVA were not fulfilled (Sokal \& Rohlf, 1981). Subsequently, a multiple comparison of means or a non-parametric multiple comparison of samples was applied (Sokal \& Rohlf, 1981; Sachs, 1982). If more than one station, season or macrobenthic group was included in a test run, abundance data had to be corrected for general abiotic and biotic differences among stations, seasons and faunal groups which were not due to the activity of the lugworms. Within each set of data (i.e. all data within one cell of the type station $\times$ season $\times$ group), the abundance values of all funnel, cast and control samples were divided by the mean of the control samples; i.e. the mean of the controls was adjusted to one for each data set without changing the relation of the variances among funnel, cast and control samples. 
TABLE 2. Appearance of funnel and cast of Arenicola marina burrows at the four stations.

Types a-c refer to figure 1 in Rijken (1979)

\begin{tabular}{|c|c|c|}
\hline Station & Funnel & Cast \\
\hline $\mathrm{KF}$ & $\begin{array}{l}\text { Only entrance to burrow visible, no } \\
\text { depression of surface }\end{array}$ & $\begin{array}{l}\text { No casts, only a few } \mathrm{cm} \text { of faeces visible, due to } \\
\text { permanent destruction by waves }\end{array}$ \\
\hline GF & $\begin{aligned} & \text { Summer: } \text { conical depression of several } \mathrm{cm} \\
& \text { depth } \\
& \text { entrance to burrow not visible } \\
& \text { (Type b) }\end{aligned}$ & $\begin{array}{l}\text { Summer: flat-rounded casts up to about } \\
10 \mathrm{~cm} \text { diameter }\end{array}$ \\
\hline & Winter: not visible & Winter: no casts, only strings of faeces \\
\hline $\mathrm{BE}$ & $\begin{array}{l}\text { Steep and deep, with well defined brink } \\
\text { (between Type b and Type c) }\end{array}$ & $\begin{array}{l}\text { Maximum diameter }>15 \mathrm{~cm} \text {, higher and with } \\
\text { steeper slope compared to } \mathrm{GF}\end{array}$ \\
\hline WH & $\begin{array}{l}\text { Flat and shallow, entrance to burrow visible } \\
\text { (Type a) }\end{array}$ & $\begin{array}{l}\text { During one low water period growth to } 7 \mathrm{~cm} \\
\text { diameter and } 4 \mathrm{~cm} \text { height on average, complete } \\
\text { erosion of casts by each tide }\end{array}$ \\
\hline
\end{tabular}

For the comparison of strength and direction (positive or negative) of funnel and cast effects among stations, seasons and faunal groups, abundance values of funnel and cast samples were transformed to per cent of the corresponding control sample. Different sets of funnel or cast data were compared by the multivariate techniques described above.

\section{Local migration of Arenicola marina}

Changes in the position of the funnel or the cast of a single specimen were observed in the field as well as in the laboratory. Fourteen animals between 15 and $100 \mathrm{~mm}$ length were kept in a circulating seawater system at $12^{\circ} \mathrm{C}$ for $10-30$ days in a $1250-\mathrm{cm}^{2}$ tray, which was filled with a $20-\mathrm{cm}$ layer of natural sediment from station GF. Each change in the position of the funnel (if detectable) and the cast was recorded.

\section{Results}

Arenicola marina abundance and burrow type

During summer, abundance was estimated from the numbers of inhabited burrows to 2-8 individuals $\mathrm{m}^{-2}$ at station $\mathrm{KF}$ (September 1987), 5-30 individuals $\mathrm{m}^{-2}$ at station GF (summer 1986-88), 5-10 individuals $\mathrm{m}^{-2}$ at station BE (May 1988), and 5-15 individuals $\mathrm{m}^{-2}$ at station WH (July 1987). During winter, abundance was lower at KF (0-2 individuals $\mathrm{m}^{-2}$, December 1987), GF (0-3 individuals $\mathrm{m}^{-2}$, February 1988) and WH (0-5 individuals $\mathrm{m}^{-2}$ November 1987, March 1988), whereas no decrease was observed at station BE in February 1988.

The visible parts of the burrows (funnel and cast) appeared different at the four stations (Table 2). Only at WH did they correspond to the typical Wadden Sea burrow as described by Rijken (1979) and others.

\section{Arenicola marina local migration}

Field observations indicated different rates of local migration of $A$. marina at the four stations. At KF, there was no evidence of local migration. At GF, video and diver observations showed clearly that $A$. marina changes its position frequently, at least the position 


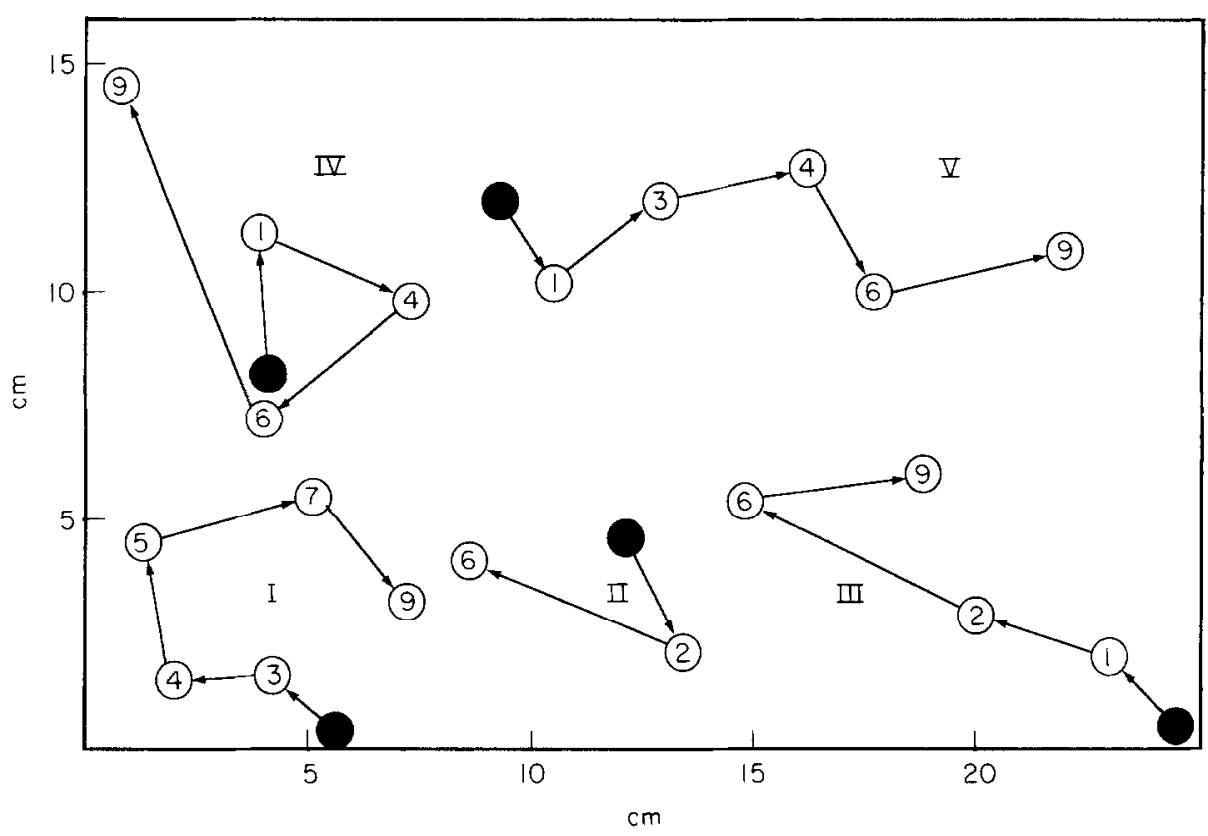

Figure 1. Composite figure of tracks of local migration of five Arenicola marina (15$30 \mathrm{~mm}$ length) during 10 days. Marks indicate position of cast, funnel usually not visible. , Day zero, start of observation. Numbers: first day at position indicated by circle.

of the cast. It is possible to separate casts which are still being added to from casts which are not. Casts which are being produced show freshly produced faecal strings on top; they form well defined mounds and are of bright, whitish colour. Abandoned casts show no faecal strings; with time they become more and more levelled out, and their colour changes towards the ambient greenish sediment surface colour. At BE only a small number of 'old ' casts was observed, indicating that $A$. marina changes its position not as frequently as at GF. At the intertidal station WH, A. marina changes the position of the funnels occasionally but most of the casts remain at the same spot during periods of several weeks (information kindly provided by S. Flothmann, Kiel).

In the laboratory experiments, all specimens of $A$. marina changed position about every other day (minimum 0.5 days, maximum 14 days), irrespective of individual length. In $5^{\circ}{ }^{\circ}$ of all cases observed $(N=84)$ only the position of the funnel changed, whereas in $95^{\circ} \mathrm{o}$ of all cases the positions of cast and funnel (if detectable) changed. The larger animals migrated up to $20 \mathrm{~cm}$ on one occasion. Figure 1 shows the migration tracks of five small specimens (15-30 $\mathrm{mm}$ length) during 10 days of observation.

The macrozoobenthos of the four stations

At all stations the macrobenthic community (Table 3 ) is dominated by surface or subsurface deposit feeders and by species which are able to feed from the sediment surface as well as from the water column, such as the bivalve Macoma balthica or the spionid polychaete Pygospio elegans. Only a few carnivorous species are present, e.g. the polychaetes Anaitides maculata and Eteone longa. The number of macrobenthic species found was 12 at $\mathrm{KF}, 43$ at $\mathrm{GF}, 46$ at BE, and 21 at WH. The dominant taxa were oligochaetes, Nereis diversicolor and Mya arenaria at KF, Pygospio elegans, Aricidea jeffreysii and Macoma balthica at GF, 
TABLE 3. List of macrobenthic taxa found at the four stations. Mean abundance $(N$ $100 \mathrm{~cm}^{2}$ ) calculated from all samples

\begin{tabular}{|c|c|c|c|c|c|}
\hline \multirow[b]{2}{*}{ Taxon } & \multirow{2}{*}{$\begin{array}{l}\text { Mobility } \\
\text { type }\end{array}$} & \multicolumn{4}{|c|}{ Station } \\
\hline & & KF & GF & $\mathrm{BE}$ & WH \\
\hline \multicolumn{6}{|l|}{ Mollusca } \\
\hline Arctica islandica & $S$ & - & 0.9 & $1 \cdot 2$ & - \\
\hline Astarte borealis & $S$ & - & $1 \cdot 3$ & $4 \cdot 1$ & - \\
\hline Astarte elliptica & $S$ & - & 0 & $2 \cdot 2$ & - \\
\hline Cardium edule & $S$ & $1 \cdot 4$ & - & - & $5 \cdot 5$ \\
\hline Cardium fasciatum & $S$ & - & $3 \cdot 3$ & $0 \cdot 6$ & - \\
\hline Corbula gibba & $\mathrm{M}$ & - & $5 \cdot 4$ & $32 \cdot 4$ & - \\
\hline Ensis sp. (juveniles) & $\mathbf{S}$ & - & - & - & 0.5 \\
\hline Macoma balthica & $S$ & $7 \cdot 6$ & $30 \cdot 2$ & $15 \cdot 0$ & $99 \cdot 3$ \\
\hline Macoma calcarea & $\mathrm{S}$ & - & - & 3.9 & - \\
\hline Musculus discors & $S$ & - & - & $1 \cdot 2$ & - \\
\hline Musculus marmoratus & $S$ & - & 0.5 & - & - \\
\hline Mya arenaria & $\mathbf{S}$ & $39 \cdot 9$ & $2 \cdot 5$ & $1 \cdot 3$ & $10 \cdot 1$ \\
\hline Mya truncata & $S$ & - & - & $3 \cdot 7$ & - \\
\hline Mysella bidentata & $\mathbf{S}$ & $\cdots$ & $19 \cdot 7$ & $57 \cdot 6$ & --- \\
\hline Mytilus edulis & $S$ & - & $2 \cdot 4$ & - & $0 \cdot 1$ \\
\hline Phaxas pellucidus & $S$ & - & $<0 \cdot 1$ & - & - \\
\hline Syndosmya alba & $S$ & - & 0.5 & $13 \cdot 3$ & - \\
\hline Acera bullata & M & - & - & $0 \cdot 1$ & - \\
\hline Hydrobia sp. & $M$ & 0.6 & $0 \cdot 3$ & - & $18 \cdot 9$ \\
\hline Littorina littorea & $M$ & - & $<0 \cdot 1$ & - & - \\
\hline Onoba striata & $M$ & - & 1.4 & $1 \cdot 3$ & - \\
\hline Retusa obtusa & $M$ & - & - & - & 1.6 \\
\hline Retusa truncatula & M & - & $0 \cdot 4$ & $0 \cdot 9$ & - \\
\hline \multicolumn{6}{|l|}{ Polychaeta and Oligochaeta } \\
\hline Ampharete sp. & $S$ & - & $0 \cdot 2$ & 0.9 & - \\
\hline Anaitides maculata & $M$ & - & 0.5 & 0.9 & $1 \cdot 2$ \\
\hline Arenicola marina (juveniles) & $\mathbf{S}$ & - & 0.5 & $0 \cdot 3$ & - \\
\hline Aricidea jeffreissii & M & - & $34 \cdot 3$ & $2 \cdot 9$ & - \\
\hline Capitella capitata & $M$ & $5 \cdot 3$ & 1.9 & $0 \cdot 6$ & 0.5 \\
\hline Chaetozone setosa & $M$ & - & $20 \cdot 6$ & $15 \cdot 0$ & - \\
\hline Eteone longa & $M$ & $7 \cdot 3$ & $2 \cdot 0$ & - & $1 \cdot 4$ \\
\hline Euchone papillosa & $\mathrm{S}$ & - & $\ldots$ & 0.6 & - \\
\hline Fabricia sabella & $S$ & - & - & - & $25 \cdot 3$ \\
\hline Fabriciola sp. & $\mathrm{S}$ & - & $<0.1$ & - & (Continued) \\
\hline
\end{tabular}

Mysella bidentata, Corbula gibba and Chaetozone setosa at BE, and P. elegans, M. balthica and Corophium volutator at WH.

Average macrofauna abundance in the $0.50-\mathrm{mm}$ sieve fraction $(0.50 \mathrm{~mm}+0.25 \mathrm{~mm}$ in parentheses) was 540 individuals $\mathrm{m}^{-2}(810)$ at $\mathrm{KF}, 330$ individuals $\mathrm{m}^{-2}$ (450) at $\mathrm{GF}, 220$ individuals $\mathrm{m}^{-2}(280)$ at $\mathrm{BE}$ and 590 individuals $\mathrm{m}^{-2}(860)$ at WH during the time of investigation. The communities at the four stations are characterized by a low-level trophic structure (sensu Menge \& Sutherland, 1987), both with respect to the food web and the interaction web (Brey, 1989).

\section{Effects of Arenicola marina burrows on macrobenthos abundance}

Prior to any detailed analysis, a four-way ANOVA was applied to all data (Table 4) in order to identify general effects of stations, seasons, macrofaunal groups and burrow 
TABLE 3. (Continued)

\begin{tabular}{|c|c|c|c|c|c|}
\hline \multirow[b]{2}{*}{ Taxon } & \multirow{2}{*}{$\begin{array}{l}\text { Mobility } \\
\text { type }\end{array}$} & \multicolumn{4}{|c|}{ Station } \\
\hline & & $\mathrm{KF}$ & GF & $\mathrm{BE}$ & WH \\
\hline Harmothoe spp. & $\mathbf{M}$ & - & $1 \cdot 8$ & $2 \cdot 7$ & - \\
\hline Heteromastus filiformis & $\mathbf{M}$ & - & - & $3 \cdot 0$ & $12 \cdot 1$ \\
\hline Malacoceros tetroceratus & $M$ & - & $<0 \cdot 1$ & - & - \\
\hline Nepthys spp. & $M$ & - & 1.9 & $7 \cdot 3$ & - \\
\hline Nereimyra punctata & $M$ & - & - & 0.7 & - \\
\hline Nereis diversicolor & $M$ & $40-1$ & - & - & $9 \cdot 7$ \\
\hline Ophelia rathkei & $M$ & - & $<0 \cdot 1$ & - & - \\
\hline Paraonis fulgens & $M$ & - & - & 0.8 & - \\
\hline Paraonis gracilis & $M$ & - & - & 0.5 & - \\
\hline Pectinaria koreni & $S$ & - & $1 \cdot 6$ & $7 \cdot 8$ & - \\
\hline Pherusa plumosa & $S$ & - & - & $2 \cdot 4$ & - \\
\hline Pholoe minuta & M & - & $3 \cdot 4$ & 5.9 & - \\
\hline Polydora ciliata & $S$ & $8 \cdot 6$ & - & 2.6 & $1 \cdot 2$ \\
\hline Polydora quadrilobata & $\mathrm{S}$ & - & $11 \cdot 4$ & $4 \cdot 7$ & - \\
\hline Pygospio elegans & $S$ & $1 \cdot 1$ & $131 \cdot 2$ & 1.9 & $305 \cdot 2$ \\
\hline Scoloplos armiger & $\mathbf{M}$ & - & $10 \cdot 8$ & $7 \cdot 3$ & $7 \cdot 9$ \\
\hline Sphaerodoridium balticum & M & - & $0 \cdot 8$ & $0 \cdot 2$ & - \\
\hline Spiogoniocephala & $\mathrm{S}$ & $3 \cdot 3$ & $1 \cdot 5$ & $1 \cdot 7$ & - \\
\hline Streptosyllis websteri & $M$ & - & $10 \cdot 0$ & $2 \cdot 8$ & - \\
\hline Terebellides stroemi & $S$ & - & - & $1 \cdot 3$ & - \\
\hline Trochochaeta multisetosa & $\mathrm{M}$ & - & - & 0.6 & - \\
\hline Oligochaeta & M & $421 \cdot 3$ & 3.9 & $1 \cdot 3$ & $30 \cdot 9$ \\
\hline \multicolumn{6}{|l|}{ Crustacea } \\
\hline Bathyporeia sp. & $\mathrm{M}$ & - & - & - & $6 \cdot 0$ \\
\hline Caprella sp. & $\mathrm{S}$ & - & $6 \cdot 3$ & 0.6 & 一 \\
\hline Carcinus sp. (juveniles) & $\mathrm{M}$ & - & - & - & $0 \cdot 8$ \\
\hline Corophium insiduosum & $S$ & $2 \cdot 2$ & $2 \cdot 4$ & - & - \\
\hline Corophium volutator & $S$ & - & - & - & $47 \cdot 3$ \\
\hline Crangon crangon & $M$ & - & - & - & 0.5 \\
\hline Diastylis rathkei & $M$ & - & $3 \cdot 5$ & $3 \cdot 7$ & - \\
\hline Eudorellopsis deformis & $M$ & - & 0.1 & $0 \cdot 1$ & 一 \\
\hline Gastrosaccus spinifer & $\mathbf{M}$ & - & $0 \cdot 6$ & 0.5 & 一 \\
\hline Idotea baltica & $M$ & - & 0.5 & - & - \\
\hline Phoxocephalus holboelli & $M$ & - & $9 \cdot 2$ & $1 \cdot 3$ & 一 \\
\hline
\end{tabular}

$S$, Sessile (including hemisessile); $M$, motile.

structures. Bivalves and gastropods were pooled for this analysis due to the low overall abundance and frequency of gastropods. The direct effects of stations, seasons and faunal groups are not significant; they were eliminated by the a priori transformation of the data to equal means of controls (see above). A. marina funnels and casts affect macrobenthic abundance significantly $(P<0.001)$. The highly significant interaction terms indicate that the effects of funnels and casts are different among stations $(P<0.001)$, between seasons $(P=0.007)$ and among faunal groups $(P<0.001)$.

Tables 5 to 8 show the results of one-way ANOVAs and subsequent multiple comparisons of funnel, cast and control samples at the four stations, for all seasons as well as for summer and winter separately. All species present were analysed, but those not affected significantly $(a=0.05)$ are not included in the Tables. At the very shallow station KF (Table 5) only one species (i.e. $8 \%$ ), the bivalve Cardium edule, is affected significantly. Its abundance is zero in the cast samples. At GF (Table 6), 13 species (i.e. $30 \%$ ) are affected 
TABLE 4. Multiple analysis of variance of differences in abundance among samples

\begin{tabular}{lrrrrr}
\hline & $\begin{array}{c}\text { Sum of } \\
\text { squares }\end{array}$ & df & $\begin{array}{c}\text { Mean } \\
\text { square }\end{array}$ & $F$ & \multicolumn{1}{c}{$P$} \\
\hline Station & 0.047 & 3 & 0.016 & 0.173 & 0.914 \\
Season & 0.002 & 1 & 0.002 & 0.021 & 0.884 \\
Group & 0.032 & 2 & 0.011 & 0.120 & 0.948 \\
Burrow & 4.816 & 2 & 2.408 & 26.687 & $<0.001$ \\
Station $\times$ burrow & 3.653 & 6 & 0.609 & 6.747 & $<0.001$ \\
Season $\times$ burrow & 0.913 & 2 & 0.456 & 5.075 & 0.007 \\
Group $\times$ burrow & 2.904 & 4 & 0.484 & 5.363 & $<0.001$ \\
Error & 88.793 & 984 & 0.090 & & \\
\end{tabular}

Abundance data were adjusted to equal means $(=1.0)$ of control samples in all cells (station $\times$ season $\times$ group) by the transformation $N_{i}=N_{i} /$ mean $_{\text {control }}$ of all values $N_{i}$.

Source: Stations, KF, GF, BE, WH; seasons, summer (June-September), winter (October-May); group, molluscs, sessile polychaetes, motile polychaetes, crustaceans; burrow, funnel, cast, control.

significantly. The molluscs are affected more or less similarly at all taxonomic levels. During winter no effects are detectable, whereas during summer abundance is higher at the funnel sites and lower at the cast sites than in the controls. Funnels show stronger effects than do casts. In general, both funnels and casts reduce the abundance of polychaetes (and oligochaetes) in comparison to control sites in summer and winter. Abundance at the funnel sites is higher than at the cast sites for sessile polychaetes, and vice versa for motile species. Crustaceans are affected in the same way as polychaetes, abundance being reduced at funnel and cast sites.

At BE (Table 7) 11 species (i.e. $24 \%$ ) are affected significantly. Nearly all mollusc species show a strongly increased abundance at the funnel sites, whereas a negative effect of the casts is detectable for all species combined. The abundance of sessile polychaetes is higher at funnel sites and lower at cast sites compared to controls, except in Terebellides stroemi, which was found in control samples only. Motile polychaetes show no consistent effects; the abundance of Aricidea jeffreysii is lower at funnel sites, but the abundance of Pholoe minuta is higher. Crustaceans are affected negatively by funnels and by casts.

At the intertidal station WH (Table 8) seven species (i.e. $33 \%$ ) are affected significantly. In general, molluscs are negatively affected by casts during summer, whereas funnels only affect the gastropod Retusa obtusa. In winter, only Mya arenaria is affected weakly. The abundance of sessile polychaetes is reduced by funnels, and more so by casts during summer, but no effect is detectable in winter. Motile polychaetes are not affected at all. Crustaceans show a reduced abundance at the funnel sites in summer and winter, and the amphipod Bathyporeia sp. shows a unique distribution in summer, occurring at cast sites only.

\section{Seasonal differences in the effects of Arenicola marina burrows}

The results of the comparison of funnel and cast effects between summer and winter are shown in the last two columns of Tables 5,6 and 8 (level of significance: $a=0 \cdot 05$ ).

At KF, no significant seasonal differences could be detected. At GF, there are differences between the effects of funnels on all polychaetes, and in Polydora quadrilobata between summer (negative) and winter (n.s.). At WH, there is a seasonal difference in the 


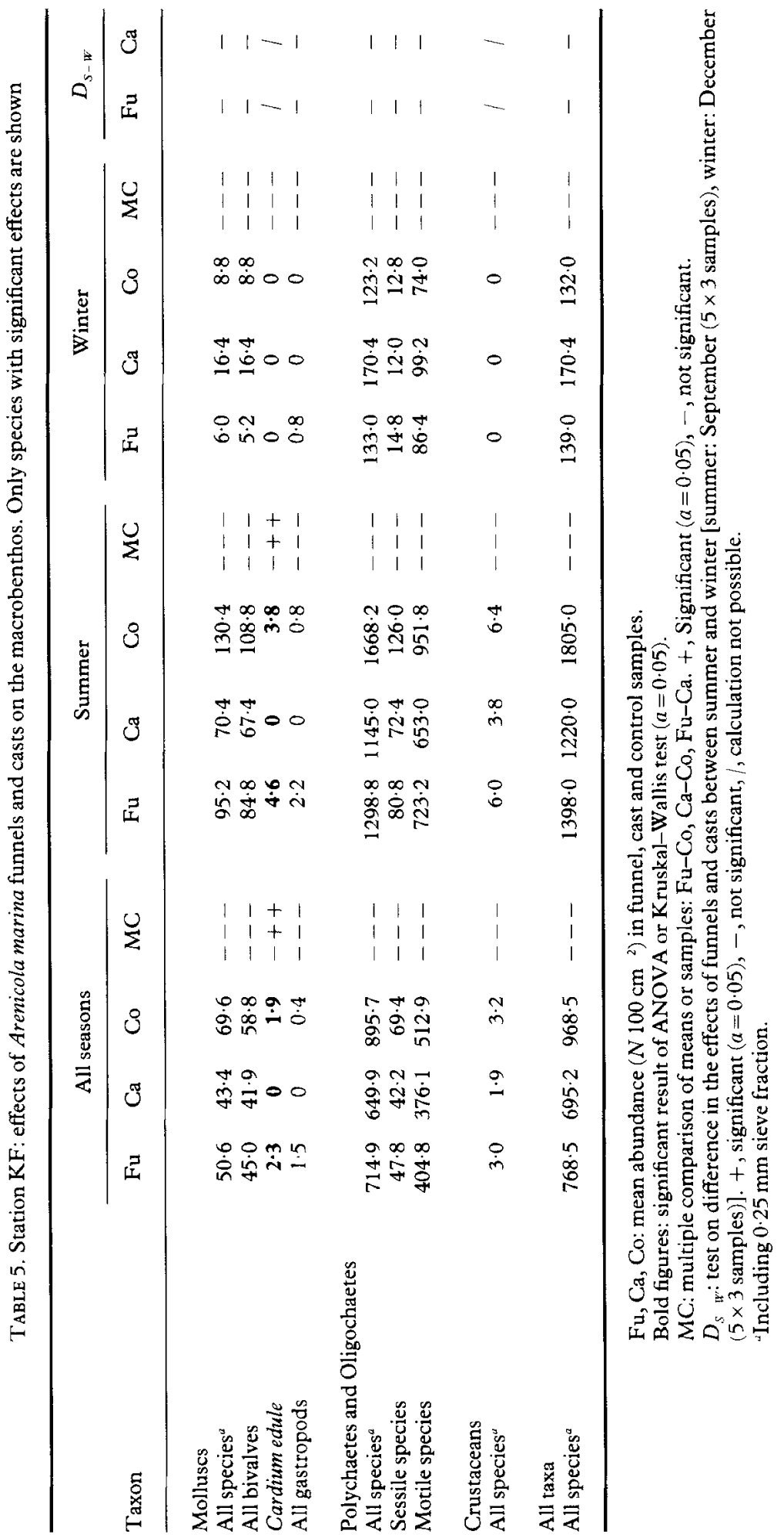




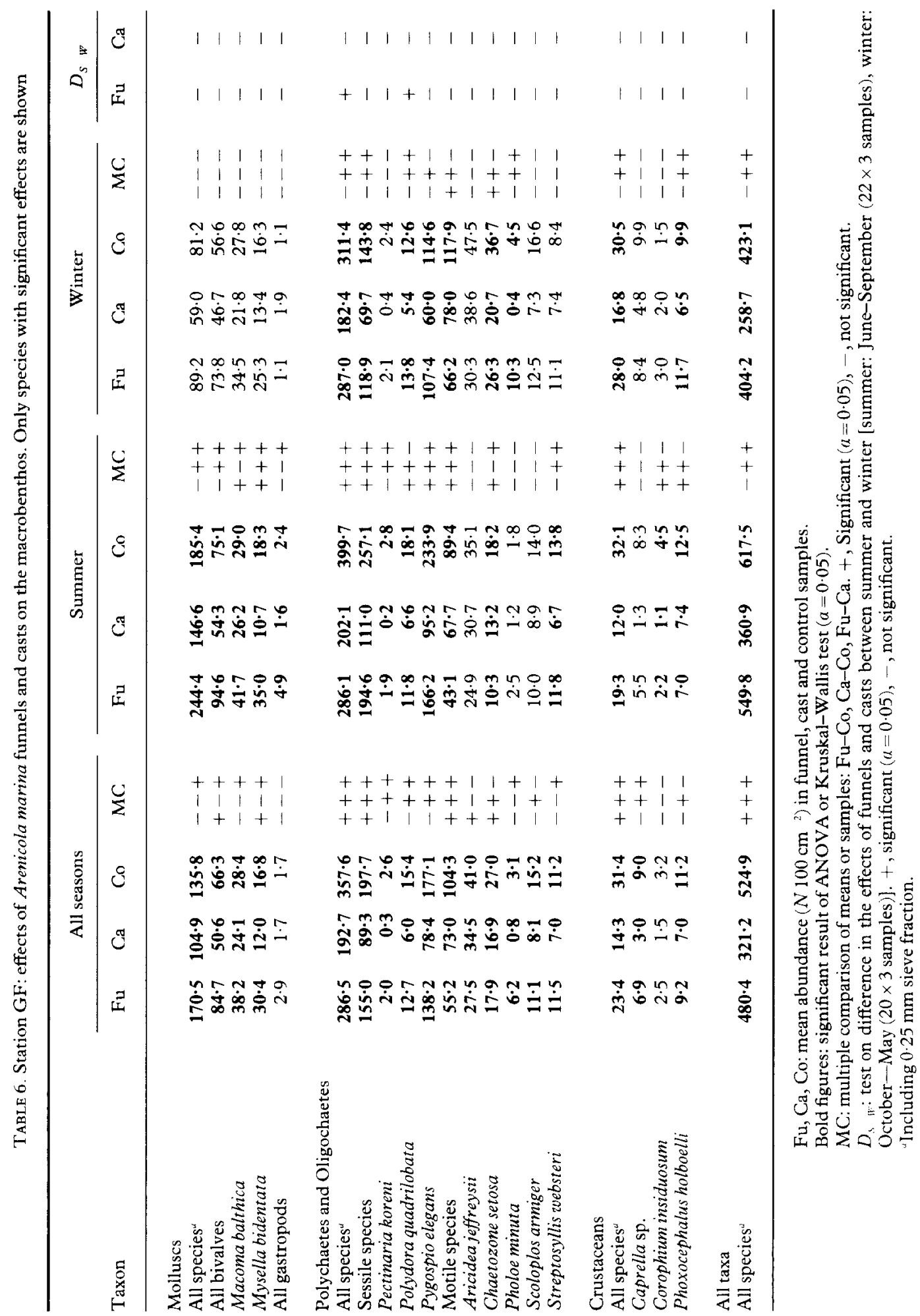


TABLE 7. Station BE: effects of Arenicola marina funnels and casts on the macrobenthos. Only species with significant effects are shown

\begin{tabular}{|c|c|c|c|c|}
\hline Taxon & $\mathrm{Fu}$ & $\mathrm{Ca}$ & Co & MC \\
\hline \multicolumn{5}{|l|}{ Molluscs } \\
\hline All species ${ }^{a}$ & $321 \cdot 9$ & $66 \cdot 1$ & $104 \cdot 1$ & +++ \\
\hline All bivalves & $270 \cdot 8$ & $55 \cdot 2$ & $84 \cdot 6$ & +-+ \\
\hline Corbula gibba & $75 \cdot 3$ & $18 \cdot 7$ & $13 \cdot 2$ & +-+ \\
\hline Macoma balthica & $20 \cdot 8$ & $10 \cdot 0$ & $14 \cdot 3$ & --+ \\
\hline Mysella bidentata & $120 \cdot 7$ & $21 \cdot 9$ & $30 \cdot 3$ & +-+ \\
\hline Syndosmya alba & $28 \cdot 5$ & $2 \cdot 8$ & $8 \cdot 4$ & +-+ \\
\hline All gastropods & $4 \cdot 4$ & $0 \cdot 3$ & $2 \cdot 2$ & --- \\
\hline Onoba striata & $3 \cdot 4$ & $0 \cdot 3$ & $\mathbf{0}$ & +-- \\
\hline \multicolumn{5}{|c|}{ Polychaetes and Oligochaetes } \\
\hline All species ${ }^{a}$ & $138 \cdot 3$ & 56.9 & $117 \cdot 6$ & -++ \\
\hline Sessile species & $52 \cdot 5$ & $9 \cdot 3$ & $28 \cdot 3$ & -++ \\
\hline Pectinaria koreni & $18 \cdot 8$ & 1.6 & $3 \cdot 1$ & --+ \\
\hline Pherusa plumosa & $5 \cdot 6$ & 0.9 & $0 \cdot 7$ & +-- \\
\hline Terebellides stroemi & 0 & 0 & $4 \cdot 0$ & $++\cdots$ \\
\hline Motile species & $56 \cdot 9$ & $35 \cdot 2$ & $45 \cdot 7$ & $--\cdots$ \\
\hline Aricidea jeffreysii & 0.3 & $3 \cdot 1$ & $4 \cdot 7$ & $+\ldots$ \\
\hline Pholoe minuta & $12 \cdot 8$ & $1 \cdot 3$ & $3 \cdot 8$ & --+ \\
\hline \multicolumn{5}{|l|}{ Crustaceans } \\
\hline All species & $5 \cdot 3$ & $3 \cdot 7$ & $10 \cdot 3$ & ++- \\
\hline Diastylis rathkei & $2 \cdot 8$ & $2 \cdot 2$ & $6 \cdot 2$ & $-+\cdots$ \\
\hline \multicolumn{5}{|l|}{ All taxa } \\
\hline All species ${ }^{a}$ & $465 \cdot 6$ & $126 \cdot 7$ & 231.9 & +++ \\
\hline
\end{tabular}

$\mathrm{Fu}, \mathrm{Ca}, \mathrm{Co}$ : mean abundance $\left(N 100 \mathrm{~cm}^{-2}\right)$ in funnel, cast and control samples. Bold figures: significant result of ANOVA or Kruskal-Wallis test $(a=0.05)$. $\mathrm{MC}$ : multiple comparison of means or samples: $\mathrm{Fu}-\mathrm{Co}, \mathrm{Ca}-\mathrm{Co}, \mathrm{Fu}-\mathrm{Ca}$. +, Significant $(a=0.05) ;-$, not significant.

"Including $0.25 \mathrm{~mm}$ sieve fraction.

effect of casts on molluscs at all levels (summer: negative; winter: n.s.) with the exception of Mya arenaria. In polychaetes, the effects of funnels and casts are different between summer (negative) and winter (n.s.), except for motile polychaetes. In crustaceans, Bathyporeia sp. shows a distinct seasonal difference in funnel and cast effects, but a statistical test could not be applied here (division by zero).

Differences in strength and direction of burrow effects among macrofaunal groups

The $A$. marina burrow effects on abundance were compared among the five macrofaunal groups (bivalves, gastropods, sessile polychaetes, motile polychaetes and crustaceans) at each station and for summer and winter separately (Figure 2). At KF no significant differences could be detected, and thus it is not included in Figure 2. At GF, the funnel effects differ in summer between bivalves (positive) and polychaetes (negative) + crustaceans (negative), and between gastropods (positive) and crustaccans. In winter only bivalves (positive) and sessile polychaetes (negative) are affected differently. All cast effects are negative in summer, but there are differences between crustaceans and bivalves + motile polychaetes, and between sessile and motile polychaetes. In winter there are differences between gastropods (n.s.) and bivalves (n.s.) + polychaetes (negative), 


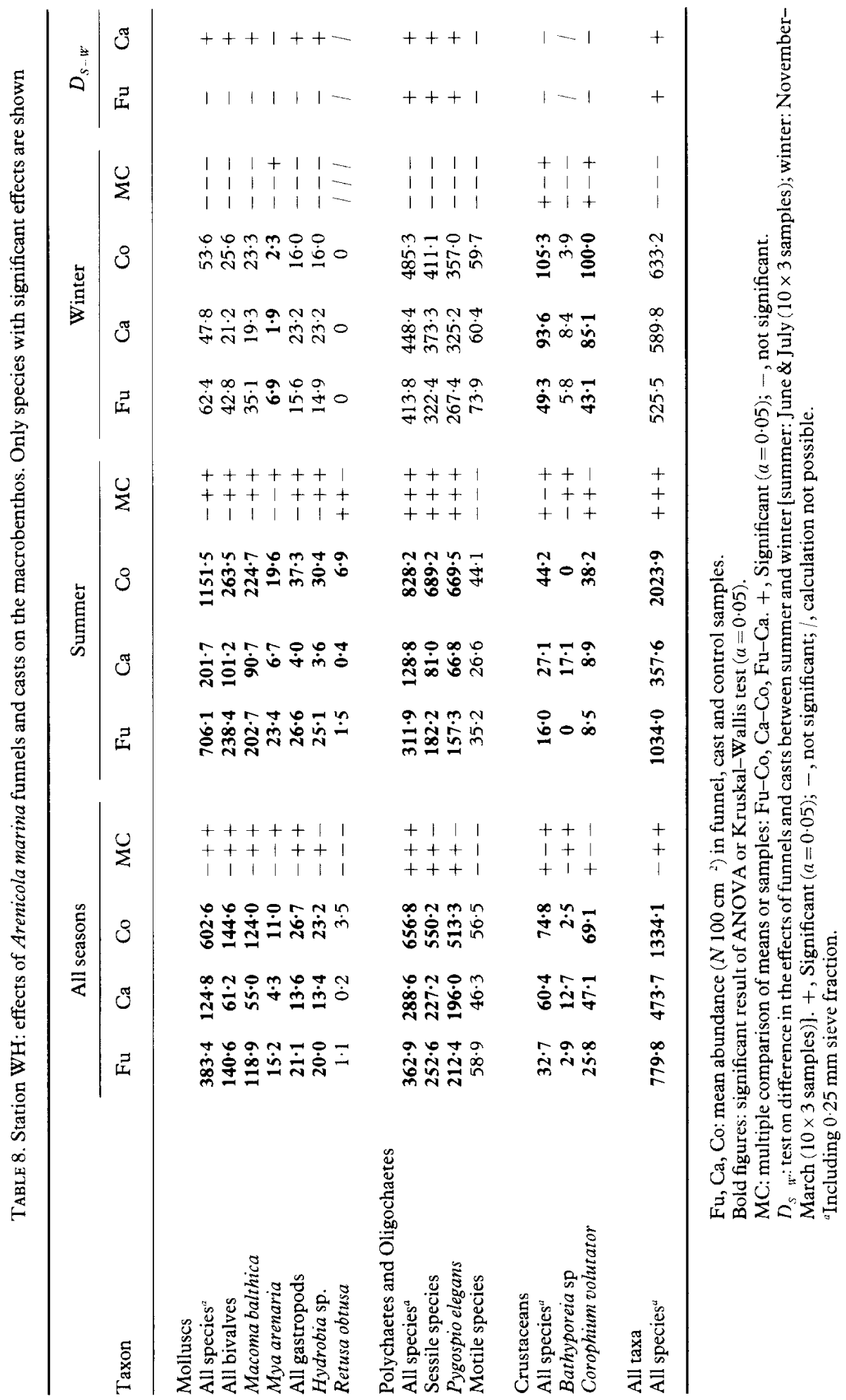




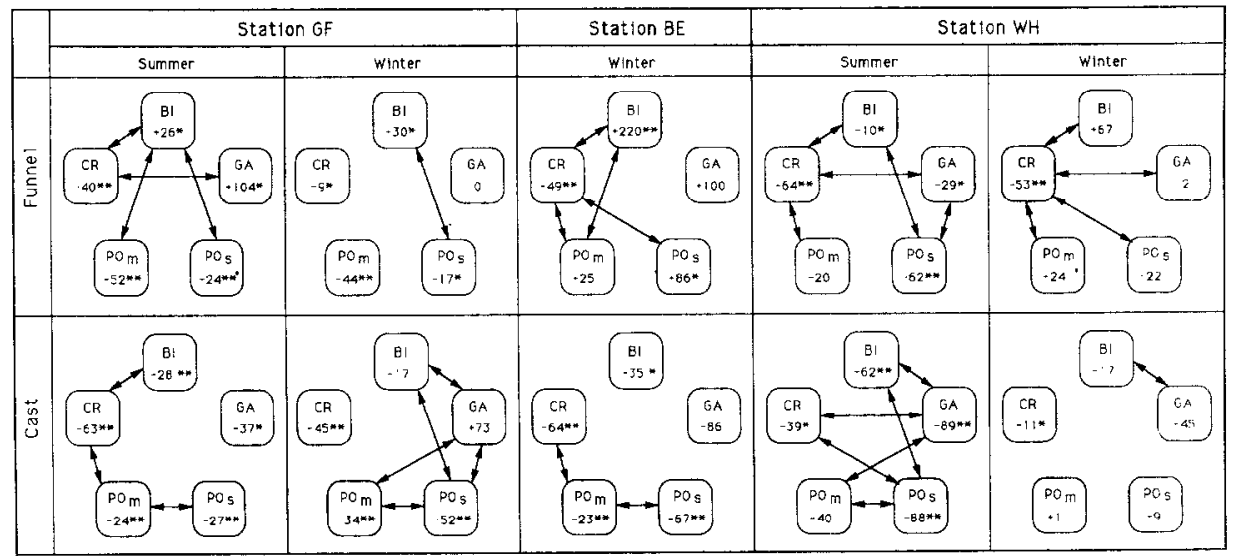

Figure 2. Differences in the effects of Arenicola marina burrows among macrofaunal groups. Arrows: significant $(a=0.05)$ difference in the effect of funnels or casts. BI, bivalves; $\mathrm{GA}$, gastropods; $\mathrm{PO}_{\mathrm{s}}$, sessile polychaetes; $\mathrm{PO}_{\mathrm{m}}$, motile polychaetes; $\mathrm{CR}$, crustaceans. Figures indicate average deviation $(\%)$ from control abundance. ${ }^{\star}$ Significant difference among funnel, cast and control samples (ANOVA). ${ }^{\star}$ Significant difference between particular burrow site and control samples.

between bivalves and sessile polychaetes, and between sessile polychaetes and motile polychaetes.

At BE, the effect of funnels is different between crustaceans (negative) and bivalves (positive) + polychaetes (positive), and between bivalves and crustaceans + sessile polychaetes. All cast effects are negative, but different between motile polychaetes and sessile polychaetes + crustaceans.

At WH, the effects of funnels differ in summer between bivalves + gastropods and crustaceans + sessile polychaetes, and between motile polychaetes (n.s.) and crustaceans, although they are negative in all groups. In winter, the crustaceans (negative) differ from all the other groups (n.s.). In summer the cast effects, which are negative in all groups, are stronger in gastropods + sessile polychaetes than in the other groups, whereas in winter only gastropods (n.s.) and bivalves (n.s.) are affected differently.

\section{Differences among stations}

Figure 3 shows the results of the comparison of $A$. marina burrow effects among the four stations and with respect to macrofaunal groups and seasons. Gastropods are not included in Figure 3, because no significant differences were detected in this group.

For bivalves, funnel effects are different between KF (n.s.) and GF (negative) in summer, and between BE (negative) and GF (n.s.) + WH (n.s.) in winter. Casts show different effects only in summer, the negative effect being stronger at WH than at GF. For sessile polychaetes, the negative funnel effect is stronger at WH than at GF in summer. In winter there is a difference between BE (positive) and GF (negative). Significant cast effects are always negative; in summer they are stronger at WH than at $\mathrm{KF}$ and $\mathrm{GF}$, and in winter they are weaker at WH (n.s.) than at GF and BE.

Different effects on motile polychaetes were found in winter only. The negative funnel effect at GF differs from the weak effects at BE and WH in summer, and the negative cast effect at GF differs from the insignificant effect at WH. For crustaceans, the negative effect of funnels is stronger at WH than at GF in both seasons. 


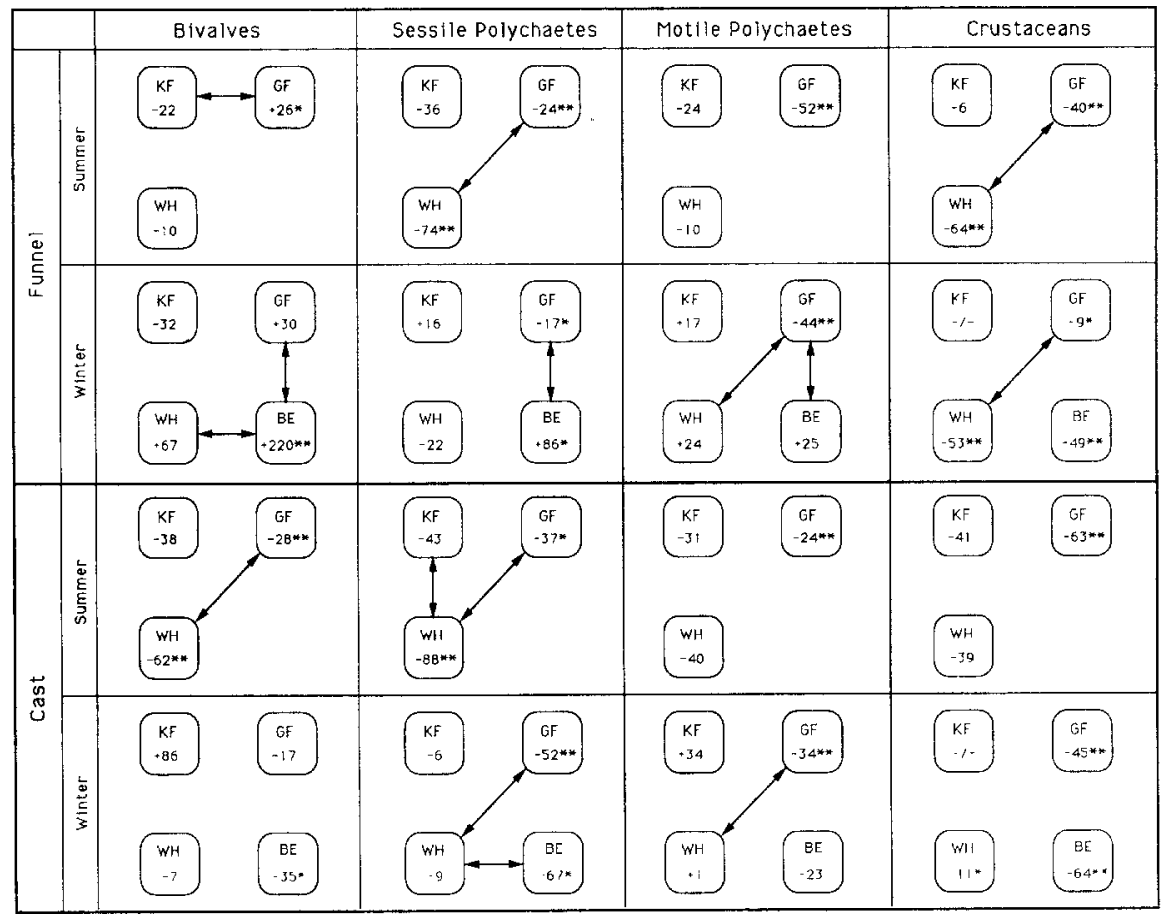

Figure 3. Differences in the effects of Arenicola marina burrows among stations. Arrows: significant $(a=0 \cdot 05)$ difference in the effect of funnels or casts. Station BE was not sampled during summer.

\section{Discussion}

Arenicola marina local migration

The frequent change of the position of funnel and cast, which was observed both at station GF and in laboratory experiments using natural sediments from this station conflicts with the observations of Rijken (1979), Schwarz (1939), Thamdrup (1935), Wells (1944) and others. All these authors agree that the position of the funnel may change quite frequently, but the position of the casts usually remains constant over weeks. However, all these observations refer to animals and sediments from intertidal flats with sediments rich in organic content ( $>1 \%$, see e.g. Cadée, 1976; Linke, 1939), whereas the present observations refer to a subtidal sandy flat with a much lower organic content (about $0.3^{\circ} \%$ ).

The combination of a more compacted sediment with the tidal cycle determines the nature of the typical Wadden Sea burrow (station WH, Table 3). Here the funnel is flat and shallow and the lugworm feeds mainly on material from the sediment-water interface, which is very rich in bacteria, microflora, microfauna and detritus. Tides and waves continuously provide new food. In contrast, the less compacted sediment at station GF precludes the formation of stable funnels, and the animal has to feed on the whole sediment column, which is not as rich in food as the sediment-water interface. Therefore it may be that $A$. marina exhausts its food resource at one locality within a few days and has to move to another, unexploited area. At the vacated site, bacterial and microfaunal abundances then presumably recover until colonization by a lugworm occurs again. 
Effects of Arenicola marina funnels and casts on macrobenthos abundance The Results section outlines the differences in the effects of funnels and casts of $A$. marina with respect to macrofaunal groups and species (Tables 5-8, Figure 2), seasons (Tables 5-8), and stations (Figure 3). To explain these observed effects, qualitative models can be developed, which include the activities of $A$. marina, the macrofauna, and the hydrodynamic conditions.

The effects of Arenicola marina funnels. The effects of the funnels are not consistent, neither among stations nor among macrobenthic groups. Molluscs, especially small species such as Mysella bidentata, show increased abundance at the funnel sites at stations $\mathrm{GF}$ and $\mathrm{BE}$. The positive funnel effect on bivalves differs significantly from the effect of funnels on other faunal groups, especially in summer, and also from the effect of funnels on bivalves at other stations, which is not significant in most cases. Sessile polychaetes are affected negatively by the funnels at stations GF and WH. This effect does not differ between seasons at GF, but does at $\mathrm{WH}$, where it is significantly stronger than at GF in summer and not present in winter. At BE the abundance of sessile polychaetes is significantly increased at the funnel sites, except for Terebellides stroemi.

The effect of funnels on motile polychaetes is negative at GF but insignificant at the other stations (significant difference between GF and BE + WH in winter). This difference may be related to the dominance of small infaunal species at GF such as Aricidea jeffreysii (which is also negatively affected at station $\mathrm{BE}$ ) and Chaetozone setosa. Motile epibenthic species are not affected, e.g. Anaitides maculata (GF, BE, WH), or show increased abundance at the funnel sites, e.g. Pholoe minuta (GF, BE) and Streptosyllis websteri (GF). Crustaceans are affected negatively in both seasons and at all stations with the exception of KF. The strongest effect is found at WH (significantly stronger than at $\mathrm{GF}$ ), where the tube-building amphipod Corophium volutator is the most abundant species.

In order to explain this somewhat confusing picture, three factors must be taken into account: (1) behaviour and living mode of the species considered, (2) $A$. marina feeding activity, and (3) hydrodynamic conditions.

(1) Species behaviour: The crucial point is whether or not an animal is able to select or change its position actively in relation to a funnel site. Recruitment via free-swimming larvae may allow for an active choice of the place of settlement. A motile or hemisessile lifestyle enables the adult animal to migrate in and out of the funnel site. However, larvae and adults may also be passively redistributed by wave and current impact.

(2) A. marina feeding activity: With respect to this factor, a funnel can be interpreted as a flow-through system, through which surface sediment is transported laterally from the edge of the funnel depression to the centre and downward from the centre to the depth of the lugworm itself. This transport also includes those animals which are not able to escape actively.

(3) Hydrodynamic conditions affect the performance of funnels as particle traps (see Aller \& Aller, 1986; Savidge \& Taghon, 1988) directly via resuspension and sedimentation and indirectly via sediment type and the corresponding funnel type. The latter also affects the lateral/downward transport of surface sediment (see above). The relations between these three factors determine whether the abundance of a certain species at a funnel site is above, below, or equal to control site abundance. Figure 4 illustrates these interactions.

The abundance of motile species will depend on the attractivity of the funnel sites, which may provide more food for scavengers such as Pholoe minuta (GF, BE) or Onoba 


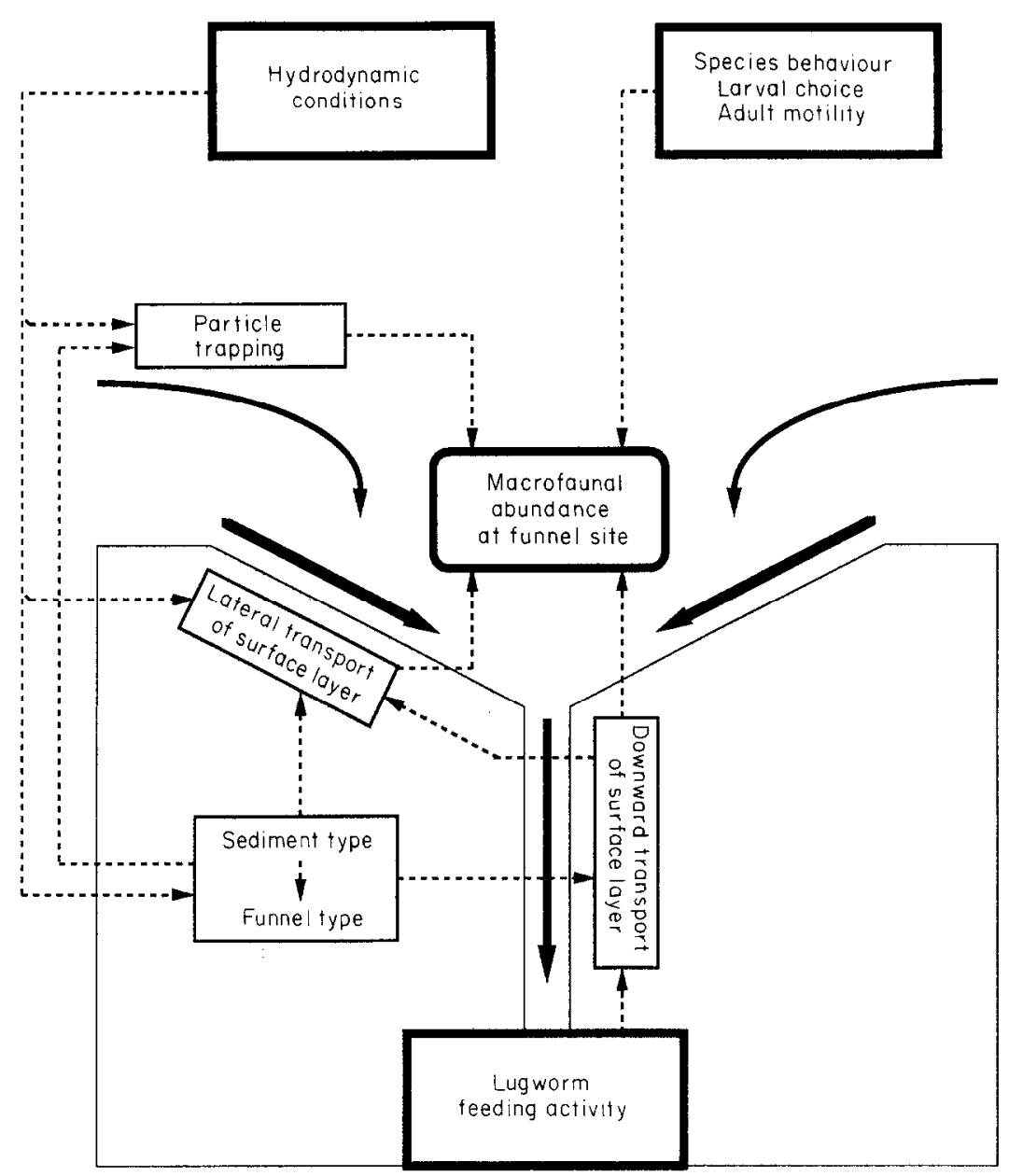

Figure 4. Factors controlling macrofaunal abundance at the site of an Arenicola marina feeding funnel. Stippled arrows indicate direction of control.

striata (BE) or better shelter from predators. Motile and hemisessile surface and subsurface deposit feeders (e.g. Aricidea jeffreysii, Chaetozone setosa, Pygospio elegans or Corophium spp.) show reduced abundances at the funnel sites. Adult specimens may avoid the funnels or emigrate, as described by Brenchley (1981) and Wilson (1981), and/or funnel sites may be avoided by settling larvae (Butman, 1987; Woodin, 1985). The sessile polychaete Terebellides stroemi, of which very small specimens were only found in the control samples at station $\mathrm{BE}$, may be another example of active habitat selection by settling larvae.

The increased abundance of small molluscs in the funnel samples at the subtidal stations $\mathrm{BE}$ and GF (summer only), and of sessile polychaetes at station BE but not at the stations KI and WH (see Figure 3), may be related to the different funnel types. At KF the hydrodynamic conditions prevent the formation of funnel depressions; therefore, the funnels cannot act as particle traps. The deep and steep funnels at stations BE and GF enhance particle trapping, but they reduce the downward transport of surface sediment; thus immotile small macrobenthos is accumulated in the funnels. At the intertidal station 
WH the funnels are not so steep-sided and deep as at stations GF and BE, and so they may not be as efficient as particle traps. Additionally, in funnels of this type only the uppermost sediment layer and the animals therein are transported downward. This may lead to a higher mortality rate and may keep the abundance of the accumulated animals below control levels.

The distinct seasonal difference in the funnel effects at station $\mathrm{WH}$, with strong effects in summer and mostly weak or insignificant effects in winter, is due to the distinct seasonal changes in the hydrodynamic conditions. In winter, increased wave and current impact frequently destroy the funnel structures and redistribute small surface-living animals. In contrast, no seasonal differences arc detcctable at $\mathrm{KH}$ because the hydrodynamic impact is strong and independent of the season. At GF, the weak differences in the funnel effects correspond well to the small seasonal difference in hydrodynamic impact. No summer samples have been taken at BE, but it is most likely that at this deep station (19 $\mathrm{m})$, with a more or less constant hydrodynamic regime, the funnel effects are independent of the season.

The effects of Arenicola marina casts. In general, the casts of $A$. marina have distinct negative effects on the abundance of many macrobenthic groups and species at all stations except at KF. These effects are much stronger in summer than in winter at station WH and slightly different between seasons at $\mathrm{GF}$. In summer, most cast effects are strongest at $\mathrm{WH}$, but in winter some groups are significantly more strongly affected at GF and BE (Figure 3). Within stations, the intensity of the cast effects can differ among macrofaunal groups (Figure 2). Small bivalves such as Mysella bidentata (GF) or juvenile Macoma balthica (WH, summer), small motile polychaetes such as Chaetozone setosa (GF) and tube-builders such as Pectinaria koreni (GF, BE), spionids (GF, WH) or Corophium spp. (GF, WH) are especially seriously affected, as are some motile epibenthic species also, e.g. the gastropods Hydrobia sp. and Retusa obtusa (WH) and the polychaete Pholoe minuta (GF).

A simple model was developed, analogous to the funnel effects, which combines (1) species behaviour, (2) A. marina defaecation activity and (3) hydrodynamic conditions to explain the observed cast effects (Figure 5).

(1) Species behaviour: Again the motility of larval and adult animals is the crucial point (see above).

(2) A. marina defaecation: Like a funnel, a cast may be interpreted as a sediment flowthrough system. On one side, sediment is imported into this system by the defaecation activity of the lugworm (up to $80 \mathrm{~g}$ dry weight day ${ }^{-1}$, see Cadée, 1976). The faeces are deposited at the sediment surface; thus, from a benthic animal's point of view, defaecation by $A$. marina is an extreme type of sedimentation.

(3) Hydrodynamic conditions are responsible for the export of sediment from a cast via erosion. The hydrodynamic conditions affect two parameters of the cast system. These are the export rate, i.e. the amount of sediment which is eroded per unit of time, and indirectly the relation between sediment import by the lugworm and sediment export by erosion, that is the maximum accumulated amount of sediment (i.e. the size of the cast). Many motile species seem to avoid the cast sites, e.g. the polychaetes Chaetozone setosa (GF), Pholoe minuta (GF, BE) and Scoloplos armiger (GF), or the gastropods Hydrobia sp. and Retusa obtusa (WH). At the cast sites microbial activity (Reichardt, 1988) and meiofaunal abundance (Reise, 1981, 1987) are lower than in flat surface sediments; therefore casts may not offer enough food for animals depending on these sources. At WH all samples were taken during low tide, i.e. the motile animals may have preferred the wet 


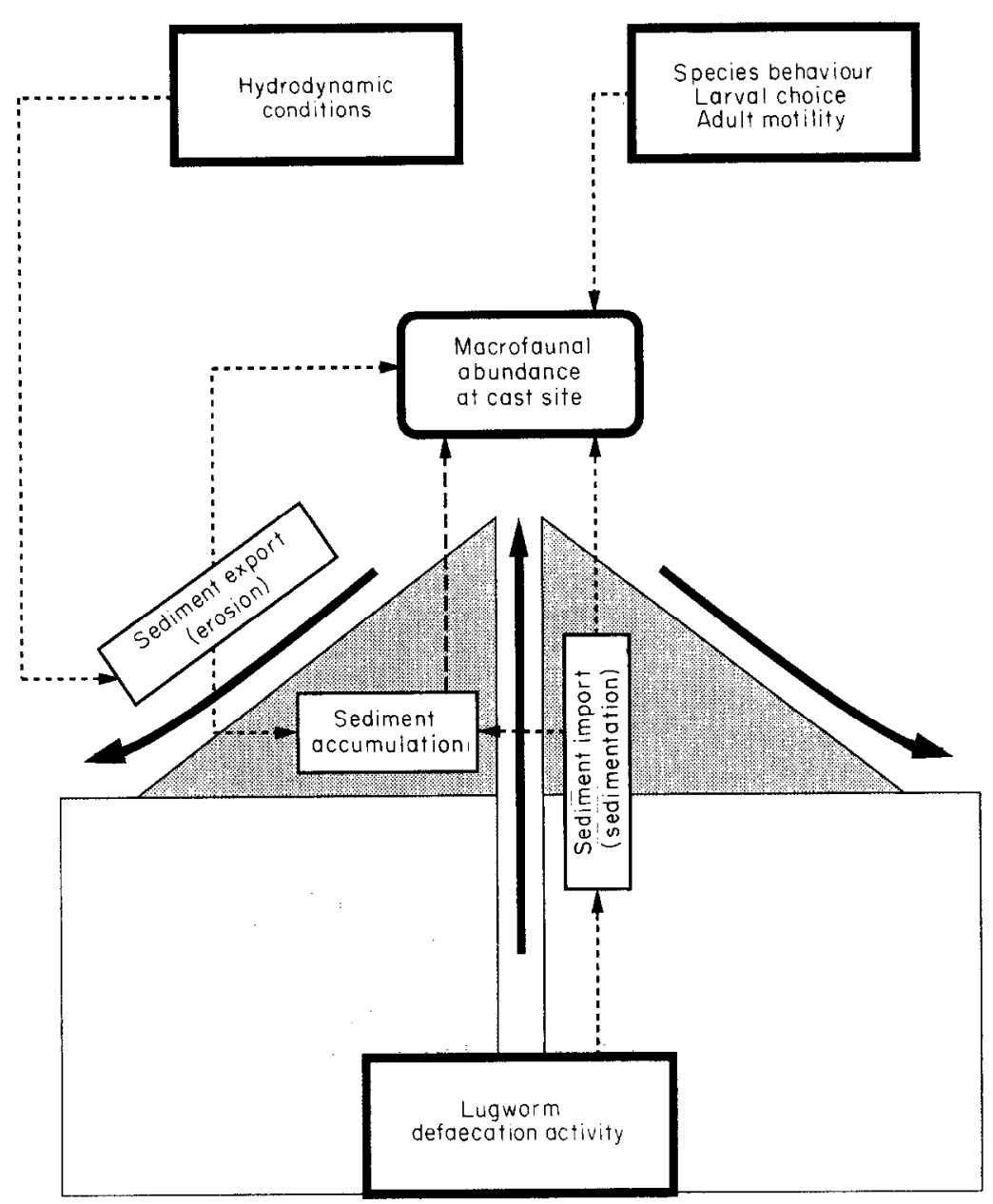

Figure 5. Factors controlling macrofaunal abundance at the site of an Arenicola marina defaecation cast. Stippled arrows indicate direction of control.

sediment surface to drier casts. The striking distribution of the amphipod Bathyporeia sp., which was found in the cast samples exclusively in summer, may be explained by its behaviour. From personal observations and information kindly provided by $F$. Buhs (Kiel), Bathyporeia sp. crawls around the sediment surface during low tide. A moving shadow, e.g. of a scientist taking samples, induces an escape reaction of the animal into the sediment of the casts.

Scssile and hemisessile species show strongly reduced abundance at the cast sites. Pelagic larvae may avoid the casts actively or may be prevented from settling at this site passively by small-scale hydrodynamic effects of the casts (see Butman, 1987). With respect to demersal recruits and adult specimens, both sediment import (i.e. sedimentation) by the lugworm and sediment export (i.e. erosion) by wave and current action may affect abundance negatively. The observations of Brenchley (1981), Turk and Risk (1981) and Wilson (1981) indicate that especially tube builders and other species of low motility which feed at the sediment surface or from the water column are negatively affected by increased sedimentation. Therefore the defaecation activity of $A$. marina is assumed to be 
one source of the observed negative cast effects. However, it is most likely that the average defaecation activity of an adult lugworm is the same at the four stations, so defaecation is not sufficient to explain the significant differences among the stations (Figure 3). Therefore, the impact of erosion has to be taken into account, as has been shown for many subtidal and intertidal species (Allen \& Moore, 1987).

At KF, each faecal string is eroded the moment it is deposited at the surface. No casts are accumulated and the rate of erosion is equal to the rate of sediment import all the time. At the subtidal stations $\mathrm{GF}$ and $\mathrm{BE}$, sediment is accumulated until a certain equilibrium size of the cast is reached. When the lugworm changes position, the abandoned cast is normally eroded slowly, only strong gales quickly eroding the casts at GF (pers. obs.). At the intertidal station WH, sediment is accumulated during low tide and also during high tide if the weather is calm, but during tidal change the casts are completely eroded within an hour. That is, in summer there is a continuous change between 6-h periods of sediment accumulation and short periods of heavy erosion, whereas during winter casts are smaller and irregular large-scale hydrodynamic events occur more frequently.

These differences in cast size (i.e. amount of accumulated sediment) and erosion (i.e. short-term sediment export rates) may explain the different strength of the cast effects among the four stations and between seasons at WH. All those animals which live and/or feed in a relatively narrow sediment horizon, either at the sediment-water interface or in some shallow depth $(\mathrm{cm})$ have to adapt their position continuously to the changing level of the sediment-water interface. The energetic costs of this adaptation may be a serious disadvantage of living at a cast site. Tube builders like Pectinaria koreni (GF, BE), spionids (all stations) or the amphipod Corophium spp. (GF, WH) have particular problems, because the tubes may be modified or damaged. Jensen (1980) made similar observations on the nematode Chromadora lorenzeni, which is also thought to be a tube builder (Jensen, pers. comm.). At a subtidal site in the Øresund (Denmark) the abundance of this species was reduced by $98 \%$ at the cast sites (and by $73 \%$ at the funnel sites). On the other hand, small free-living specimens such as most of the juvenile molluscs are unable to avoid passive redistribution due to cast erosion.

These changes in the level of the sediment-water interface are most intensive at WH during summer, where casts are produced and eroded in a 6-h rhythm. At the subtidal stations $\mathrm{GF}$ and $\mathrm{WH}$ the short-term sediment export rates are much lower than at station WH, and only during strong gales are casts eroded completely within a short period of time. Therefore, the negative effect of the casts depends on sedimentation, sediment accumulation and more or less continuous erosion at these stations. In particular small specimens which live in the sediment-water interface may have difficulties in surviving in a site of continuous sedimentation and erosion. However, they are affected to a greater extent by the high short-term sediment export rate at station WH during summer (Figure 3). At station KF, a continuous process of sedimentation and erosion occurs, but the effects on the fauna are very weak. The permanent wave-induced disturbance at this station prevents the formation of casts and the development of strong cast effects. The situation is similar at station WH during winter, when the activity of $A$. marina is lower and direct impact by non-tidal wave and current action is stronger; thus the effects of the casts are masked by hydrodynamic effects.

\section{Implications for macrobenthic community structure}

At the stations GF, BE and WH biological disturbance by $A$. marina plays an important role in the development of benthic soft-bottom community structure in space and time. 
Funnels and especially casts are patches of reduced macrobenthic abundance and different species composition. The direct effect of $A$. marina on certain species may be amplified by the strong negative effect of $A$. marina on tube builders, which has also been found by Brenchley (1981), Wilson (1981) and Woodin (1981). As shown by Gallagher et al. (1983), Neumann and Scoffin (1970), Rhoads et al. (1978), Reise (1981) and others, tube builders stabilize the sediment and facilitate colonization by other species. A. marina acts as an antagonist to this facilitation effect of tube builders.

The local migration behaviour of $A$. marina at the subtidal stations adds a dynamic component to this system of disturbed and undisturbed patches. The spatial arrangement of these patches is not constant with time, but changes continuously. A system of this kind corresponds well with the model of disturbance-induced small-scale temporal mosaics, which was developed by Grassle and Sanders (1973). A model of community regulation proposed by Menge and Sutherland (1987) predicts a shift from biological control to physical control with increasing environmental stress in communities of low trophic structure. This is in good agreement with the observed differences among stations BE, $\mathrm{GF}, \mathrm{KF}$ and $\mathrm{WH}$ (winter only). The stronger the hydrodynamic impact, the weaker are the effects of bioturbation by $A$. marina. However, biological factors (i.e. bioturbation of A. marina) do affect the community significantly at the intertidal station WH during summer, although it is exposed to distinct environmental stress (i.e. disturbance due to tides). In future investigations on the effects of small-scale biological disturbances, the hydrodynamic conditions as well as the living mode of the affected species should be taken into account to avoid generalizations which are based on singular observations.

\section{References}

Allen, P. L. \& Moore, J. J. 1987 Invertebrate macrofauna as potential indicators of sandy beach instability. Estuarine, Coastal and Shelf Science 24, 109-125.

Aller, J. Y. \& Aller, R. C. 1986 Evidence for localized enhancement of biological activity associated with tube and burrow structures in deep-sea sediments at the HEBBLE site. Deep Sea Research 33, 755-790.

Asmus, R. 1984 Benthische und pelagische Primärproducktion und Nährsalzilanz. Eine Freilanduntersuchung im Watt der Nordsee, Berichte Institut für Meereskunde Kiel (Germany) 131, pp. 148.

Babenerd, B. 1980 Untersuchungen zur Produktionsbiologie des Planktons in der Kieler Bucht. Dissertation Univ. Kiel (Germany), pp. 226.

Bell, S. S. \& Devlin, D. J. 1983 Short-term macrofaunal recolonization of sediment and epibenthic habitats in Tampa Bay, Florida. Rulletin of Marine Science 33, 102-108.

Boehlich, M. J. \& Blackhaus, J. O. 1987 Simulation windangeregter Strömungen im System Nordsee-Ostsee zur Interpretation eutro-phierungsrelevanter biologisch-chemischer Prozesse in deutschen Küstengewässern. Umweltforschungsplan des Bundesministers für Umwelt, Naturschutz und Reaktorsicherheit, Forschungsbericht 102-04-215/18, pp 52.

Brenchley, G. A. 1981 Disturbance and community structure: an experimental study of bioturbation in marine soft-bottom environments. Fournal of Marine Research 39, 767-790.

Brey, T. 1989 Der Einfluß physikalischer und biolugischer Fakturen auf Struktur und Dynamik der sublitoralen Macoma-Gemeinschaft der Kieler Bucht (The effect of physical and biological factors on structure and dynamics of the sublitoral Macoma community in Kiel Bay). Berichte Institut für Meereskunde Kiel (Germany) 186, pp. 248.

Butman, C. A. 1987 Larval settlement of soft sediment invertebrates: the spatial scales of patterns explained by active habitat selection and the emerging role of hydrodynamical processes. Oceanography and Marine Biology Annual Review 25, 113-165.

Cadee G. C. 1976 Sediment reworking by Arenicola marina on tidal flats in the Dutch Wadden Sea. The Netherlands fournal of Sea Research 10, 440-460.

Connell, J. H. \& Slayter, R. O. 1977 Mechanisms of succession in natural communities and their role in community stability and organization. American Naturalist 111, 1119-1144.

DeWitt, T. H. 1987 Microhabitat selection and colonization rates of a benthic amphipod. Marine Ecology Progress Series 36, 237-250.

Duncan, P. B. 1977 Burrow-structure and burrowing activity of the funnel-feeding enteropneust Balanoglossus aurantiacus in Boque Sound, North Carolina, USA. Marine Ecology 8, 75-95. 
Eckman, J. E. 1979 Small-scale patterns and processes in a soft-substratum, intertidal community. Fournal of Marine Research 37, 437-457.

Gallagher, E. D., Jumars, P. A. \& Trueblood, D. D. 1983 Facilitation of soft-bottom benthic succession by tube builders. Ecology 64, 1200-1216.

Grassle, J. F. \& Sanders, H. L. 1973 Life histories and the role of disturbance. Deep Sea Research 20,643-659.

Gray, J. 1977 The stability of benthic ecosystems. Helgoländer Wissenschaftliche Meeresuntersuchungen 30, 427-444.

Gray, J. 1984 Ökologie Mariner Sedimente. Springer-Verlag, Berlin, pp 193.

Hall, S. J., Raffaelli, D. J., Basford, D. J. \& Robertson, M. R. 1990 The importance of flatfish predation and disturbance on marine benthos: an experiment with dab Limande limanda (L.). Fournal of Experimental Marine Biology and Ecology 136, 65-76.

Huston, M. 1979 A general hypothesis of species diversity. American Naturalist 113, 81-101.

Jensen, P. 1980 Description of the marine free-living nematode Chromadora lorenzeni $\mathrm{n}$. sp. with notes on its microhabitats. Zoologischer Anzeiger fena 205, 213-218.

Linke, O. 1939 Die Biota des Jadebusenwattes. Helgoländer Wissenschaftliche Meeresuntersuchungen 1, 201-348

MacArthur, R. H. \& Wilson, E. O. 1967 The Theory of Island Biogeography. Princeton University Press, Princeton, New Jersey.

Menge, B. A. \& Sutherland, J. P. 1987 Community regulation: variation in disturbance, competition, and predation in relation to environmental stress and recruitment. American Naturalist 130, 730-757.

Myers, A. C. $1977 a$ Sediment processing in a marine subtidal sandy bottom community. I Physical aspects. Fournal of Marine Research 35, 608-632.

Myers, A. C. $1977 b$ Sediment processing in a marine subtidal sandy bottom community. II Biological consequences. Fournal of Marine Research 35, 633-647.

Neumann, A. C. \& Scoffin, T. P. 1970 The composition, structure and erodability of subtidal mats, Abaco, Bahamas. Fournal of Sedimentology and Petrology 40, 274-297.

Paine, R. T. 1966 Food web complexity and species diversity. American Naturalist 100, 65-75.

Probert, P. K. 1984 Disturbance, sediment stability and trophic structure of soft-bottom communities. Fournal of Marine Research 42, 893-921.

Reichardt, W. 1988 Impact of bioturbation by Arenicola marina on microbiological parameters in intertidal sediments. Marine Ecology Progress Series 44, 149-158.

Reise, K. 1981 High abundance of small zoobenthos around the biogenic structures in tidal sediments of the Wadden Sea. Helgoländer Wissenschaftliche Meeresuntersuchungen 34, 413-425.

Reise, K. 1987 Spatial niches and long-term performance in meiobenthic platyhelminthes of an intertidal lugworm flat. Marine Ecology Progress Series 38, 1-11.

Rhoads, D. C. \& Young, D. K. 1971 Animal-sediment relations in Cape Cod Bay, Massachusetts. II. Reworking by Molpadia oolitica (Holo-thuroidea). Marine Biology 11, 255-261

Rhoads, D. C., Yingst, J. Y. \& Ullman, W. J. 1978 Seafloor stability in central Long Island Sound: Part I. Temporal changes in erodibility of fine-grained sediment. In Estuarine Interactions (Wiley, M. L., ed.). Academic Press, New York, pp. 221-244.

Rijken, M. 1979 Food and food uptake in Arenicola marina. Netherlands fournal of Sea Research 13, $406-421$.

Sachs, L. 1982 Applied Statistics. A Handbook of Techniques. Springer-Verlag, New York, pp. 706.

Sanders, H. L. 1968 Marine benthic diversity: a comparative study. American Naturalist 102, 243-282.

Savidge, W. B. \& Taghon, G. L. 1988 Passive and active components of colonization following two types of disturbance on an intertidal sandflat. Fournal of Experimental Marine Biology and Ecology 115, $137-155$.

Schwarz, A. 1939 Der tierische Einfluß auf die Meeressedimente. Senckenbergiana 14, 118-172.

Schweimer, M. 1976 Errosionshäufigkeit in der westlichen Ostsee als Folge des Seegangs. University Kiel SFB 95 Report No. 21, pp. 59.

Smith, C. R., Jumars, P. A. \& De Master, D. J. 1986 In situ studies of megafunal mounds indicate rapid sediment turnover and community response at the deep-sea floor. Nature 323, 251-253.

Sokal, R. R. \& Rohlf, F. J. 1981 Biometry. 2nd cdn. Frecman \& Co., San Francisco, pp. 859.

Stienen, C. 1986 Die Phytoplanktonentwicklung in Abhängigkeit von der Nährsalzkonzentration. Ein Vergleich zwischen Kieler Förde und Kieler Bucht. Berichte Institut für Meereskunde Kiel (Germany) No. 152, pp. 146.

Struve-Blanck, S. 1982 Die Strömungen in der Kieler Bucht. Berichte Institut für Meereskunde Kiel (Germany) No. 102, pp. 112.

Thamdrup, H. M. 1935 Beiträge zur Ökologie der Wattenfauna auf experimenteller Grundlage. Meddelelser fra Kommissionen for Danmarks Fiskeri og Havundersogelser, Serie Fiskeri 10, 1-125.

Thrush, S. F., Pridmore, R. D., Hewitt, J. E. \& Cummings, V. J. 1991 Impact of ray feeding disturbances on sandflat macrobenthos: do communities dominated by polychaetes or shellfish respond differently? Marine Ecology Progress Series 69, 245-252.

Turk, T. R. \& Risk, M. J. 1981 Effect of sedimentation on infaunal invertebrate populations in Chesapeake Bay. Ecology 58, 1199-1217. 
van Blaricom, G. R. 1982 Experimental analysis of structural regulation in a marine sand community exposed to oceanic swell Ecology 52, 283-305.

Wells, G. P. 1944 The mode of life of Arenicola marina L. Journal of the Marine Biological Association of the United Kingdom 26, 170-207.

Wilson, W. H. 1981 Sediment-mediated interactions in a densely populated infaunal assemblage: the effects of the polychaete Abarenicola pacifica. Fournal of Marine Research 39, 735-748.

Woodin, S. A. 1978 Refuges, disturbance, and community-structure: a marine soft-bottom example. Ecology 59, 1052-1066.

Woodin, S. A. 1981 Disturbance and community structure in a shallow water sand flat. Ecology 62, $1052-1066$.

Woodin, S. A. 1985 Effects of defecation by arenicolid polychaete adults on spionid polychaete juveniles in field experiments: selective settlement or differential mortality. Fournal of Experimental Marine Biology and Ecology 87, 119-132.

Zajac, R. N. \& Whitlatch, R. B. 1982 Responses of estuarine infauna to disturbance. II. Spatial and temporal variation of succession. Marine Ecology Progress Series 10, 15-27. 